\title{
Narasin inclusion for feedlot lambs fed a diet containing high amounts of ground flint
}

\section{corn}

Daniel Montanher Polize ${ }^{1 *} \oplus$, Samuel Sutil Marques ${ }^{2} \odot$, Mariana Fontana Westphalen ${ }^{3} \odot$, Vinícius Nunes Gouvea ${ }^{4}$, Marcos Vinícius de Castro Ferraz Júnior ${ }^{\oplus}$, Alexandre Arantes Miszura ${ }^{6}$, José Paulo Roman Barroso ${ }^{6} \odot$, Arnaldo Cintra Limede ${ }^{6}$, Evandro Maia Ferreira ${ }^{1}$, Alexandre Vaz Pires ${ }^{1} \odot$

IUniversidade de São Paulo/ESALQ - Depto. de Zootecnia, Av. Pádua Dias, 11 - 13418-900 - Piracicaba, SP - Brasil. 2Universidade Estadual de Ponta Grossa - Depto. de Zootecnia, Av. General Carlos Cavalcanti, 4748 84030-900 - Ponta Grossa, PR - Brasil.

3Pennsylvania State University/College of Agricultural Sciences - Dept. of Animal Science, 351 AG SC IN Bldg. University Park - 16802 - Pennsylvania - USA.

${ }^{4}$ New Mexico State University/College of Agricultural, Consumer and Environmental Sciences/Clayton Livestock Research Center, 15 NMSU Lane - 88415 - Clayton, NM - USA.

5Universidade Federal do Amazonas - Depto. de Zootecnia, Rod. Parintins Macurany, 1805 - 69152-240 - Parintins, AM - Brasil.

${ }^{6}$ Universidade de São Paulo/FMVZ - Depto. de Nutrição e Produção Animal, Av. Duque de Caxias Norte, 225 - 13635000 - Pirassununga, SP - Brasil.

*Corresponding author < danielpolizel@usp.br>

Edited by: Antonio Faciola

Received January 22, 2020

Accepted July 10, 2020
ABSTRACT: Narasin is an antibacterial agent that may change rumen fermentation. Two experiments were proposed to evaluate the efficiency of narasin inclusion for lambs fed a diet containing high amounts of ground flint corn. Thirty rumen-cannulated wethers were used to evaluate nutrient digestibility, nitrogen balance, and rumen metabolism (Exp. 1); and forty-five lambs were used to evaluate performance (Exp. 2) of animals fed with narasin for high flint corn diets. The experimental diets were: control or basal diet without additives (C); $25 \mathrm{mg}$ of monensin $\mathrm{kg}^{-1}$ of dry matter (DM) (M); and inclusion of 5 (N5), 10 (N10), and 15 (N15) mg of narasin $\mathrm{kg}^{-1}$ of DM. The statistical analyses were performed using the MIXED procedure of SAS. Monensin increased DM digestibility compared to $C(p=0.01)$ and increasing doses of narasin linearly increased DM digestibility $(p<0.01)$. There was a quadratic effect $(p=0.10)$ for molar proportion of acetate peaking at N15. Monensin inclusion increased ( $p=0.07$ ) propionate compared to $\mathrm{C}$; however, it did not differ from narasin. The increasing levels of narasin linearly decreased the total volatile fatty acids concentration in the rumen $(p=0.02)$. Monensin and $C$ showed a similar performance. The increasing levels of narasin linearly increased $(p \leq 0.04)$ average daily gain and feed efficiency. Monensin and narasin changed rumen fermentation and improved overall nutrient digestibility. However, lambs that received narasin showed improved performance when compared with animals that received $\mathrm{M}$.

Keywords: average daily gain, feed efficiency, propionate, rumen metabolism, sheep

\section{Introduction}

Production efficiency of ruminants depends on ruminal fermentation, which may be optimized through improving the quality of dietary ingredients by processing or by manipulating rumen microorganisms to increase energy retention by the animal while decreasing environmental impacts. Flint corn is the primary grain source used in feedlot diets in Brazil (Oliveira and Millen, 2014). Flint corn has a greater proportion of vitreous endosperm than dent corn does (Philippeau et al., 1999), which may be associated with lower ruminal degradation of starch. The use of feed additives is one of the most efficient ways of handling ruminal fermentation and improving nutrient use (Bergen and Beates, 1984; Tedeschi et al., 2003).

Monensin and narasin are highly lipophilic molecules that act on the cell membrane of bacteria (Pressman, 1976), reducing the population and activity of Gram-positive bacteria and protozoa (McGuffey et al., 2001), and possibly inhibiting fungal growth (Bergen and Bates, 1984). However, response level to supplementation of feed additives could be affected by grain processing (Meyer et al., 2013). Recent studies have shown that narasin does not affect the dry matter intake (DMI), but it does increase concentration of propionate (Pasqualino et al., 2020) and volatile fatty acids (VFA) (Polizel et al., 2020). In addition, the use of narasin increased the total milk production (Assis et al., 2020) and the plasma glucose concentration in sheep at the end of lactation (Sardinha et al., 2020). To our knowledge, information is scarce in the scientific literature comparing inclusion of monensin and narasin in finishing diets of lambs fed a high proportion of ground flint corn.

We hypothesize that narasin, similarly to monensin, alters ruminal fermentation, resulting in changes on nutrient digestibility, $\mathrm{N}$ balance and performance of lambs fed diets containing high amounts of ground flint corn. In order to test our hypothesis, two experiments were conducted to evaluate the effects of increasing narasin levels in diets with high amounts of ground flint corn: one experiment aimed to evaluate rumen fermentation, nutrient digestibility, and $\mathrm{N}$ balance (Exp. 1), while the other trial evaluated the diet performance (Exp. 2). 


\section{Materials and Methods}

Two experiments were carried out with lambs fed high-energy diets with large amounts of ground flint corn to evaluate levels of narasin addition on digestibility, ruminal fermentation and performance. The experiments were conducted in Piracicaba, state of São Paulo, Brazil $\left(22^{\circ} 43^{\prime} 0^{\prime \prime}\right.$ S, 47 $38^{\prime} 51^{\prime \prime}$ W, altitude of $528 \mathrm{~m})$. Both experiments were reviewed and approved by the Animal Care and Use Committee (protocol number 9433031014).

\section{Experiment 1}

Thirty F1 wethers (Dorper $\times$ Santa Inês) with an initial body weight (BW) $58.5 \pm 2.2 \mathrm{~kg}$ and approximately nine months of age, provided with rumen fistula, were used to evaluate the treatment effects on nutrient digestibility and ruminal fermentation. Wethers were dewormed with subcutaneous moxidectin at a dosage of $1 \mathrm{~mL} 50 \mathrm{~kg}^{-1} \mathrm{BW}$ and received $2 \mathrm{~mL}$ of subcutaneous ADE vitamin (A vitamin: 250,000 $\mathrm{UI} \mathrm{mL}^{-1}$; D3 vitamin:

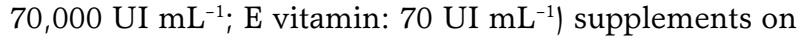
the right side of the neck, five days before the beginning of the experiment. The wethers were placed in metabolism crates $(1.30 \times 0.55 \mathrm{~m})$ that were fitted with a feed bunk, a waterer, and a system for feces and urine collection. The metabolism crates were kept indoors protected from direct sunlight and rain. The experiment lasted 29 days, and the experimental design was a randomized complete block, with five experimental diets and six replications. The wethers were blocked according to initial BW.

The experimental diets were defined by the inclusion of feed additives, monensin (Rumensin 200, Elanco Brazil, São Paulo, SP, Brazil) or narasin (Zimprova, Elanco Brazil, São Paulo, SP, Brazil). The experimental diets were as follows: control or basal diets without feed additives $(\mathrm{C}) ; 25 \mathrm{mg}$ of monensin $\mathrm{kg}^{-1}$ of dry matter (DM) ( $\mathrm{M}$ - positive control); diet with $5 \mathrm{mg}$ of narasin $\mathrm{kg}^{-1}$ of $\mathrm{DM}$ (N5); $10 \mathrm{mg}$ of narasin $\mathrm{kg}^{-1}$ of DM (N10); and $15 \mathrm{mg}$ of narasin $\mathrm{kg}^{-1}$ of DM (N15). The diets were formulated according to NRC (2007) recommendations for growing lambs $(25 \mathrm{~kg}$ of $\mathrm{BW}$ and $300 \mathrm{~g}$ of average daily gain; ADG). The proportion of ingredients and chemical diets composition are presented in Table 1.

Corn and coast-cross hay were coarsely passed through a $10-\mathrm{mm}$ sieve in a grinder and mixed with concentrate composed of soybean, urea, limestone, mineral mix, ammonium chloride, and feed additives (when treated) using a horizontal mixer with a capacity of $500 \mathrm{~kg}$. In both trials, the experimental diets were weighed on an electronic scale with an accuracy of $1 \mathrm{~g}$ and offered ad libitum at 08h00.

The orts were recorded daily to determine the DMI. A sample was taken daily from offered feed and orts of each experimental unit, composed by animal and kept at $-18{ }^{\circ} \mathrm{C}$ for analysis. To determine nutrient digestibility in the total digestive tract and $\mathrm{N}$ balance on days 25 through 28 of the experiment, the total fecal and
Table 1 - Ingredients and chemical composition of the diets containing high inclusion of flint corn with and without inclusion of monensin and narasin.

\begin{tabular}{|c|c|c|c|c|c|}
\hline \multirow{2}{*}{ Item } & \multicolumn{5}{|c|}{ Diets $^{1}$} \\
\hline & C & M & N5 & N10 & N15 \\
\hline \multicolumn{6}{|l|}{ Ingredient proportion } \\
\hline Coastcross hay ( $\mathrm{g} \mathrm{kg}^{-1}$ of DM) & 100 & 100 & 100 & 100 & 100 \\
\hline Corn ( $\mathrm{g} \mathrm{kg}^{-1}$ of $\left.\mathrm{DM}\right)$ & 720 & 720 & 720 & 720 & 720 \\
\hline Soybean meal ( $\mathrm{g} \mathrm{kg}^{-1}$ of DM) & 140 & 140 & 140 & 140 & 140 \\
\hline Urea ( $\mathrm{g} \mathrm{kg}^{-1}$ of DM) & 5.0 & 5.0 & 5.0 & 5.0 & 5.0 \\
\hline Mineral mix ${ }^{2}\left(\mathrm{~g} \mathrm{~kg}^{-1}\right.$ of DM) & 15.0 & 15.0 & 15.0 & 15.0 & 15.0 \\
\hline Ammonium chloride ( $\mathrm{g} \mathrm{kg}^{-1}$ of DM) & 5.0 & 5.0 & 5.0 & 5.0 & 5.0 \\
\hline Limestone (g kg-1 of DM) & 15.0 & 15.0 & 15.0 & 15.0 & 15.0 \\
\hline Monensin ${ }^{3}\left(\mathrm{mg} \mathrm{kg}^{-1}\right)$ & 0.0 & 25.0 & 0.0 & 0.0 & 0.0 \\
\hline $\operatorname{Narasin}^{4}\left(\mathrm{mg} \mathrm{kg}^{-1}\right)$ & 0.0 & 0.0 & 5.0 & 10.0 & 15.0 \\
\hline \multicolumn{6}{|l|}{ Chemical composition $^{5}$} \\
\hline \multicolumn{6}{|l|}{ Experiment 1} \\
\hline $\mathrm{DM}\left(\mathrm{g} \mathrm{kg}^{-1}\right.$ as fed) & 872 & 870 & 870 & 872 & 869 \\
\hline $\mathrm{OM}$ ( $\mathrm{g} \mathrm{kg}^{-1}$ of DM) & 941 & 944 & 946 & 944 & 945 \\
\hline $\mathrm{CP}\left(\mathrm{g} \mathrm{kg}^{-1}\right.$ of $\left.\mathrm{DM}\right)$ & 176 & 180 & 177 & 181 & 179 \\
\hline 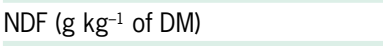 & 189 & 181 & 180 & 179 & 184 \\
\hline ADF ( $\mathrm{g} \mathrm{kg}^{-1}$ of $\left.\mathrm{DM}\right)$ & 71.2 & 67.3 & 68.8 & 67.4 & 70.0 \\
\hline $\mathrm{EE}$ ( $\mathrm{g} \mathrm{kg}^{-1}$ of DM) & 34.2 & 34.6 & 34.9 & 34.5 & 34.3 \\
\hline NFC ( $\mathrm{g} \mathrm{kg}^{-1}$ of DM) & 542 & 548 & 554 & 549 & 548 \\
\hline \multicolumn{6}{|l|}{ Experiment 2} \\
\hline $\mathrm{DM}$ ( $\mathrm{g} \mathrm{kg}^{-1}$ as fed) & 867 & 868 & 867 & 871 & 168 \\
\hline $\mathrm{OM}$ ( $\mathrm{g} \mathrm{kg}^{-1}$ of DM) & 945 & 948 & 948 & 949 & 947 \\
\hline $\mathrm{CP}\left(\mathrm{g} \mathrm{kg}^{-1}\right.$ of DM) & 180 & 179 & 182 & 179 & 183 \\
\hline NDF ( $\mathrm{g} \mathrm{kg}^{-1}$ of DM) & 183 & 183 & 180 & 182 & 189 \\
\hline ADF ( $\mathrm{g} \mathrm{kg}^{-1}$ of $\left.\mathrm{DM}\right)$ & 68.0 & 71.9 & 71.6 & 70.5 & 72.5 \\
\hline $\mathrm{EE}$ (g kg-1 of DM) & 33.8 & 34.1 & 34.2 & 34.3 & 34.4 \\
\hline $\mathrm{NFC}\left(\mathrm{g} \mathrm{kg}^{-1}\right.$ of DM) & 548 & 552 & 552 & 549 & 541 \\
\hline
\end{tabular}

${ }^{1} \mathrm{C}=$ control diets, no additives; $\mathrm{M}=25 \mathrm{mg}$ of monensin $\mathrm{kg}^{-1}$ of $\mathrm{DM}$; $\mathrm{N} 5=5$ $\mathrm{mg}$ of narasin $\mathrm{kg}^{-1}$ of DM; N10 $=10 \mathrm{mg}$ of narasin $\mathrm{kg}^{-1}$ of DM; N15 = $15 \mathrm{mg}$ of narasin $\mathrm{kg}^{-1}$ of DM; ${ }^{2}$ Composition: $13 \% \mathrm{Ca}, 8 \% \mathrm{P}, 1 \% \mathrm{Mg}, 7 \% \mathrm{~S}, 22 \%$ $\mathrm{Cl}, 15 \% \mathrm{Na}, 1,100 \mathrm{mg} \mathrm{kg}^{-1} \mathrm{Mn}, 500 \mathrm{mg} \mathrm{kg}^{-1} \mathrm{Fe}, 4,600 \mathrm{mg} \mathrm{kg}^{-1} \mathrm{Zn}, 300 \mathrm{mg}$ $\mathrm{kg}^{-1} \mathrm{Cu}, 40 \mathrm{mg} \mathrm{kg}^{-1} \mathrm{Co}, 55 \mathrm{mg} \mathrm{kg}^{-1} \mathrm{I}$, and $30 \mathrm{mg} \mathrm{kg}^{-1} \mathrm{Se}$; ${ }^{3}$ Rumensin 200 (Elanco Brazil, São Paulo, SP, Brazil); ${ }^{4}$ Zimprova (Elanco Brazil, São Paulo, SP, Brazil); ${ }^{5} \mathrm{DM}=$ dry matter; $\mathrm{OM}=$ organic matter; $\mathrm{CP}=$ crude protein; $\mathrm{NDF}=$ neutral detergent fiber; $\mathrm{ADF}$ = acid detergent fiber; $\mathrm{EE}=$ ether extract; $\mathrm{NFC}$ $=$ non-fiber carbohydrates.

urine production were individually collected every day using collection bags to avoid urine contamination. Urine was collected in containers with $6 \mathrm{~N} \mathrm{HCl}$ to prevent ammonia volatilization, keeping the $\mathrm{pH}$ below 3.0. Feces and urine were weighed at $08 \mathrm{~h} 00$ and a representative sample (10\% of the total weight) of daily production of each wether was collected and stored at $-18{ }^{\circ} \mathrm{C}$.

Rumen fluid was collected on day 29 of the experiment. Samples were collected at 0, 3, 6, 9, and $12 \mathrm{~h}$ after the feed was offered. Approximately $200 \mathrm{~g}$ of ruminal content was collected in each interval via rumen cannula and then filtered through nylon cloth. The fluid filtrate was then used to measure the $\mathrm{pH}$ in a digital potentiometer. The solid phases of the ruminal content were returned to the rumen.

At the end of the experiment, samples of feed, orts, and feces were dried in a forced-air oven at $60{ }^{\circ} \mathrm{C}$ 
for $72 \mathrm{~h}$, ground through a $1-\mathrm{mm}$ screen of a Willeytype mill and analyzed for DM at $105^{\circ} \mathrm{C}$ (AOAC, 1990; method \#934.01). Ash concentration was obtained by incinerating the samples in a furnace at $550{ }^{\circ} \mathrm{C}$ for $4 \mathrm{~h}$ (AOAC, 1990; method \#942.05). Total $\mathrm{N}$ was determined using the Leco TruMac N according to AOAC (1990; method \#968.06). Crude protein (CP) was obtained by multiplying the total $\mathrm{N}$ content by 6.25 . The sequential detergent fiber analyses were used to determine neutral detergent fiber (NDF; Van Soest et al., 1991) and acid detergent fiber (ADF; Goering and Van Soest, 1970) in an Ankom 2000 fiber analyzer. Heat-stable $\alpha$-amylase and sodium sulfite were included in the NDF analysis, and the concentration was corrected for ash. The ether extract (EE) was determined according to AOAC (1990; method \#920.39). Non-fiber carbohydrates (NFC) were estimated according to the following equation: NFC (\%) $=100 \%-(\% \mathrm{NDF}+\% \mathrm{CP}+\% \mathrm{EE}+\%$ ash $)($ Mertens, 1997).

To determine VFA, $1.8 \mathrm{~mL}$ of ruminal fluid was centrifuged for $60 \mathrm{~min}$ at $15,000 \times \mathrm{g}$ and $4{ }^{\circ} \mathrm{C}$. After centrifugation, $0.8 \mathrm{~mL}$ of the supernatant was transferred to a chromatography vial and $0.2 \mathrm{~mL}$ of $3: 1$ solution of metaphosphoric acid $\left(250 \mathrm{~mL} \mathrm{~L}^{-1}\right)$ and formic acid (980$1000 \mathrm{~mL} \mathrm{~L}^{-1}$ ) were added. The internal standard was added in each vial $10.1 \mathrm{~mL}$ of $100 \mathrm{mM}$ 2-ethyl-butyric acid). The VFA quantification was performed using Agilent 7890A gas chromatograph equipped with flame ionization detector and a fused-silica capillary column, $25 \mathrm{~m}$ in length and $320 \mu \mathrm{M}$ internal diameter, containing $0.20 \mu \mathrm{M}$ cyanopropyl polysiloxane. The chromatographic run time was divided into three heating cycles, as follows: $80{ }^{\circ} \mathrm{C}(1 \mathrm{~min}), 120^{\circ} \mathrm{C}\left(20{ }^{\circ} \mathrm{C} \mathrm{min}{ }^{-1}\right.$ for $\left.3 \mathrm{~min}\right)$, and $205^{\circ} \mathrm{C}\left(10^{\circ} \mathrm{C} \mathrm{min}^{-1}\right.$ for $\left.2 \mathrm{~min}\right)$. Hydrogen was used as the carrier gas at a flow rate of $1.0 \mathrm{~mL} \mathrm{~min}^{-1}$ and the temperature of the injector and detector was $260{ }^{\circ} \mathrm{C}$.

The ruminal ammonia concentration was determined by the colorimetric method (Chaney and Marbach, 1962) and adapted for a microplate reader with a $550 \mathrm{~nm}$ absorbance filter.

The animals were considered the experimental unit to perform the statistical analyses. All data were submitted to the Levene test to verify homogeneity of variances, while the Shapiro-Wilk test was used to check normality of the residuals and to remove outliers.

Statistical procedures were conducted using the PROC MIXED of SAS (Statistical Analysis System, version 9.0). Data for VFA, rumen $\mathrm{pH}$, and ruminal ammonia concentration were analyzed as repeated measures over time and the animal was the subject (treatment). For the analysis, the model statement contained the effects of diets, hour and diets $\times$ hour interaction. Data were analyzed using block and animal as the random effect. The covariance structure was first-order autoregressive, which provided the best fit for these analyses according to the lowest corrected Akaike information criteria value (Wang and Goonewardene, 2004). There were two contrasts preciously defined: $1-C$ vs. $M$; and $2-M$ vs. N. The effects of narasin levels (C, N5, N10, and N15) in the diets were evaluated using a linear (L) and quadratic (Q) orthogonal contrasts.

Nutrient intake, digestibility, and $\mathrm{N}$ balance were analyzed considering the fixed effect of diets and random effect of block. The means were obtained using the LSMEANS statement. The contrasts previously described were used to evaluate the effect of the experimental diets. The effects were considered significant when $p<0.10$.

\section{Experiment 2}

Forty-five lambs (Dorper $\times$ Santa Inês), with an initial BW of $25.3 \pm 0.5 \mathrm{~kg}$ and $90.5 \pm 0.8$ days of age, were used to evaluate the effect of the same experimental diets previously described (Exp. 1) on growth performance. All lambs were dewormed with subcutaneous moxidectin and received subcutaneous ADE vitamin supplements (A vitamin: 250,000 UI $\mathrm{mL}^{-1}$; D3 vitamin: 70,000 UI $\mathrm{mL}^{-1}$; E vitamin: $70 \mathrm{UI}$ $\mathrm{mL}^{-1}$ ), five days before the beginning of the experiment. The lambs were kept indoors, in an individual tiestall system, with slatted floor, a feed bunk, and a waterer. The experiment lasted 56 days, divided into four periods of 14 days. The experimental design used was randomized complete block with five experimental diets and nine replications. Lambs were blocked by age and initial BW.

The orts were recorded weekly to determine the DMI, and the feed amount was calculated according to previous intake, adjusting when needed, to ensure that refusals did not exceed $5 \%$ of daily intake. The lambs were weighed after fasting for $14 \mathrm{~h}$ at days 0 , $14,28,42$, and 56. In each interval (14 days), ADG and feed efficiency (FE) were calculated (feed intake. body weight gain $^{-1}$ ). The chemical analysis of the feed offered and orts were performed as described for Experiment 1.

Statistical procedures were conducted using the PROC MIXED for SAS (Statistical Analysis System, version 9.0). The animals were considered the experimental unit. The DMI, ADG, and FE were analyzed as repeated measures over time and the animal was subject (treatment). For the analysis, the model statement contained the effects of diets, period, and diets $\times$ period interaction. Data were analyzed using blocks and animal as the random effect. The covariance structure was first-order autoregressive, which provided the best fit for the analyses, according to lowest corrected Akaike information criteria (Wang and Goonewardene, 2004).

The BW of lambs (Exp. 2) were analyzed considering the fixed effect of diets and random effect of blocks. The means were obtained using the LSMEANS statement. The contrasts previously described were used to evaluate the effect of the experimental diets. The effects were considered significant when $p<0.10$. 


\section{Results}

Experiment 1 . The $\mathrm{M}$ diet decreased DMI $\mid p=$ $0.01)$, resulting in a lower nutrient intake when compared to $\mathrm{C}$ (Table 2). Similarly, the increasing narasin levels decreased the DMI $(p=0.02)$ and nutrient intake $(p \leq$ 0.07), except for EE intake ( $p=0.14)$.

Supplemental ionophores affected nutrient digestibility, wethers fed with $\mathrm{M}$ had greater digestibility of $\mathrm{DM}(p=0.01)$, OM $(p=0.04)$ and $\mathrm{CP}(p=0.04)$ compared to $\mathrm{C}$; however, $\mathrm{M}$ did not affect digestibility of $\mathrm{NDF}, \mathrm{ADF}, \mathrm{EE}$, and NFC. The increasing narasin levels linearly increased digestibility of DM $(p<0.01)$, OM $(p<0.01), \mathrm{CP}(p<0.01)$, EE $(p=0.02)$ and NFC $(p<$ $0.01)$. There were no differences in nutrient digestibility between $M$ and narasin levels $(\mathrm{N})$.

Effects of diet $\times$ hour were not detected $(p \geq 0.12)$ for rumen parameters evaluated in the present study (Table 3). The experimental diets did not affect the molar proportion of acetate. Wethers fed with $M$ had a greater

Table 2 - Nutrient intake and digestibility in wethers receiving the diets containing high inclusion of flint corn with and without inclusion of monensin and narasin.

\begin{tabular}{|c|c|c|c|c|c|c|c|c|c|c|}
\hline \multirow{2}{*}{ Item $^{4}$} & \multicolumn{5}{|c|}{ Diets $^{1}$} & \multirow{2}{*}{$\mathrm{SEM}^{2}$} & \multicolumn{4}{|c|}{$p$-value ${ }^{3}$} \\
\hline & C & $M$ & N5 & N10 & N15 & & $C \times M$ & $\mathrm{M} \times \mathrm{N}$ & $\mathrm{L}$ & $Q$ \\
\hline \multicolumn{11}{|c|}{ Intake $\left(\mathrm{g} \mathrm{d}^{-1}\right)$} \\
\hline DM & 1,992 & 1,659 & 1,783 & 1,872 & 1,647 & 77.9 & 0.01 & 0.24 & 0.02 & 0.92 \\
\hline OM & 1,868 & 1,556 & 1,673 & 1,759 & 1,537 & 74.2 & 0.01 & 0.26 & 0.02 & 0.86 \\
\hline NDF & 378 & 299 & 321 & 333 & 306 & 13.9 & $<0.01$ & 0.21 & 0.01 & 0.30 \\
\hline ADF & 142 & 111 & 123 & 126 & 115 & 5.31 & $<0.01$ & 0.13 & 0.07 & 0.39 \\
\hline $\mathrm{CP}$ & 350 & 297 & 314 & 339 & 293 & 13.8 & 0.01 & 0.27 & 0.05 & 0.76 \\
\hline $\mathrm{EE}$ & 76.3 & 63.8 & 70.3 & 75.2 & 66.7 & 3.01 & 0.01 & 0.16 & 0.14 & 0.68 \\
\hline NFC & 1,073 & 907 & 982 & 1,021 & 891 & 43.1 & 0.01 & 0.26 & 0.03 & 0.66 \\
\hline \multicolumn{11}{|c|}{ Digestibility (g kg-1) } \\
\hline DM & 822 & 862 & 835 & 860 & 864 & 8.91 & 0.01 & 0.42 & $<0.01$ & 0.58 \\
\hline OM & 849 & 876 & 849 & 875 & 879 & 8.64 & 0.04 & 0.42 & $<0.01$ & 0.86 \\
\hline NDF & 646 & 699 & 655 & 673 & 683 & 26.2 & 0.16 & 0.35 & 0.28 & 0.99 \\
\hline ADF & 604 & 657 & 623 & 647 & 655 & 28.0 & 0.20 & 0.65 & 0.17 & 0.84 \\
\hline $\mathrm{CP}$ & 829 & 857 & 820 & 847 & 859 & 9.38 & 0.04 & 0.17 & $<0.01$ & 0.29 \\
\hline $\mathrm{EE}$ & 916 & 916 & 906 & 920 & 939 & 7.92 & 0.98 & 0.50 & 0.02 & 0.17 \\
\hline NFC & 924 & 939 & 920 & 948 & 951 & 6.94 & 0.13 & 0.93 & $<0.01$ & 0.66 \\
\hline
\end{tabular}

${ }^{1} \mathrm{C}=$ control diets, no additives; $\mathrm{M}=25 \mathrm{mg}$ of monensin $\mathrm{kg}^{-1}$ of DM; $\mathrm{N} 5=5 \mathrm{mg}$ of narasin $\mathrm{kg}^{-1}$ of DM; $\mathrm{N} 10=10 \mathrm{mg}$ of narasin kg-1 of DM; $\mathrm{N15}=15 \mathrm{mg}$ of narasin $\mathrm{kg}^{-1}$ of DM. ${ }^{2} \mathrm{SEM}=$ standard error of mean. ${ }^{3} \mathrm{C} \times \mathrm{M}=$ control diet vs. diet containing $25 \mathrm{mg}$ of monensin kg-1 $\mathrm{DM} ; \mathrm{M} \times \mathrm{N}=\operatorname{diet}$ containing $25 \mathrm{mg}^{-}$of monensin kg${ }^{-1}$ vs. diets containing narasin; $L=$ linear effect of narasin (C, N5, N10 and N15); $Q=$ quadratic effect of narasin (C, N5, N10 and N15); ${ }^{4} \mathrm{DM}=$ dry matter; OM = organic matter; $\mathrm{NDF}=$ neutral detergent fiber; $\mathrm{ADF}=$ acid detergent fiber; $\mathrm{CP}=$ crude protein; $\mathrm{EE}=$ ether extract; $\mathrm{NFC}=$ non-fiber carbohydrates; Dietary composition was determined by analyzing subsamples collected and composited throughout the experiment ( $n=8$ samples/treatment/experiment).

Table 3 - Rumen volatile fatty acids, ammonia concentration and $\mathrm{pH}$ of wethers fed with diets containing high inclusion of flint corn with and without inclusion of monensin and narasin.

\begin{tabular}{|c|c|c|c|c|c|c|c|c|c|c|c|c|}
\hline \multirow{2}{*}{ Item $^{4}$} & \multicolumn{5}{|c|}{ Diets $^{1}$} & \multirow{2}{*}{$\mathrm{SEM}^{2}$} & \multicolumn{6}{|c|}{$p$-value ${ }^{3}$} \\
\hline & C & $M$ & N5 & N10 & N15 & & $\mathrm{C} \times \mathrm{M}$ & $\mathrm{M} \times \mathrm{N}$ & $\mathrm{L}$ & Q & $\mathrm{H}$ & $\mathrm{D} \times \mathrm{H}$ \\
\hline \multicolumn{13}{|l|}{ VFA (mM $\left.100 \mathrm{mM}^{-1}\right)$} \\
\hline Acetate & 56.4 & 53.3 & 53.4 & 51.7 & 54.7 & 2.37 & 0.22 & 0.96 & 0.35 & 0.10 & 0.08 & 0.15 \\
\hline Propionate & 26.6 & 33.4 & 31.0 & 33.7 & 30.2 & 3.18 & 0.07 & 0.55 & 0.22 & 0.14 & $<0.01$ & 0.14 \\
\hline Isobutyrate & 0.75 & 0.65 & 0.75 & 0.80 & 0.79 & 0.06 & 0.26 & 0.06 & 0.45 & 0.89 & $<0.01$ & 0.14 \\
\hline Butyrate & 13.5 & 9.36 & 11.5 & 11.1 & 11.4 & 1.11 & 0.01 & 0.08 & 0.14 & 0.22 & $<0.01$ & 0.19 \\
\hline Isovalerate & 1.57 & 1.44 & 1.62 & 1.38 & 1.62 & 0.16 & 0.54 & 0.58 & 0.74 & 0.52 & $<0.01$ & 0.99 \\
\hline Valerate & 1.24 & 1.23 & 1.53 & 1.44 & 1.31 & 0.13 & 0.96 & 0.20 & 0.90 & 0.12 & 0.01 & 0.28 \\
\hline Ac:pr ratio & 2.21 & 1.74 & 1.86 & 1.62 & 1.99 & 0.25 & 0.08 & 0.69 & 0.24 & 0.06 & $<0.01$ & 0.18 \\
\hline Total (mM) & 134 & 124 & 136 & 122 & 116 & 6.23 & 0.30 & 0.97 & 0.02 & 0.47 & $<0.01$ & 0.15 \\
\hline $\mathrm{pH}$ & 5.87 & 5.87 & 5.86 & 6.01 & 5.93 & 0.07 & 0.97 & 0.41 & 0.21 & 0.58 & $<0.01$ & 0.12 \\
\hline Ammonia ( $\mathrm{mg} \mathrm{dL}^{-1}$ ) & 24.1 & 17.4 & 20.6 & 21.8 & 19.1 & 1.51 & $<0.01$ & $<0.01$ & $<0.01$ & 0.66 & 0.63 & 0.14 \\
\hline
\end{tabular}


molar proportion of propionate than $\mathrm{C}(p=0.07)$, but with no difference from $\mathrm{N}$. The $\mathrm{M}$ decreased $(p=0.01)$ molar proportion of butyrate when compared with $\mathrm{C}$ and decreased butyrate $(p=0.08)$ and isobutyrate $(p=$ $0.06)$ when compared to $\mathrm{N}$. The experimental diets did not affect isovalerate, valerate, and ruminal $\mathrm{pH}$.

The $\mathrm{M}$ decreased $(p=0.08)$ the acetate to propionate ratio (Ac:pr). In addition, the $\mathrm{N}$ resulted in quadratic effect for Ac:pr $(p=0.06)$ with N10 presenting the lowest ratio. The $\mathrm{N}$ linearly decreased $(p=0.02)$ the total VFA; however, $\mathrm{N}$ did not differ when compared to $M(p=0.97)$. The wethers fed with $M$ had a lower ruminal ammonia concentration when compared with $\mathrm{C}$ $(p<0.01)$ and diets containing $\mathrm{N}(p<0.01)$. In addition, the increasing $\mathrm{N}$ levels linearly decreased ammonia concentration $(p<0.01)$.

Wethers fed with $\mathrm{C}$ had a greater $(p=0.02) \mathrm{N}$ intake when compared with $\mathrm{M}$. Levels of $\mathrm{N}$ decreased $(p=0.06) \mathrm{N}$ intake (Table 4$)$. In addition, $\mathrm{M}$ decreased the fecal $\mathrm{N}(p=0.01)$ and $\mathrm{N}$ absorbed $(p=0.04)$ when compared to the $\mathrm{C}$. The increasing $\mathrm{N}$ levels linearly decreased $(p<0.01)$ fecal and urinary $\mathrm{N}(p=0.04)$; however, the $\mathrm{M}$ or $\mathrm{N}$ did not affect $\mathrm{N}$ retention.
Experiment 2. Effects of diet $\times$ period were not detected for DMI, ADG, and FE ( $p \geq 0.33$; Table 5). The $\mathrm{M}$ did not affect ADG, DMI $(p=0.14)$ and FE when compared with $\mathrm{C}$; however, $\mathrm{M}$ decreased ADG $(p=0.05)$ when compared with $\mathrm{N}$. The increasing $\mathrm{N}$ levels linearly raised ADG $(p=0.03)$ and $\mathrm{FE}(p=$ 0.04), without affecting DMI. Additionally, lambs fed with $\mathrm{N}$ had a greater $\mathrm{BW}$ in all periods evaluated when compared with $\mathrm{M}$. Increasing $\mathrm{N}$ linearly increased BW of lambs on day $42(p=0.04)$ and day $56(p=0.02)$. There was no difference on BW between $\mathrm{C}$ and $\mathrm{M}$.

Effects of period were detected for ADG $(p<$ 0.01), DMI $(p<0.01)$, and FE $(p<0.01)$. The ADG increased during the periods 1,2 , and 3 , decreasing in period 4. However, as expected, DMI increased, while FE decreased over time.

\section{Discussion}

Experiment 1. Studies demonstrated that the effects of ionophore on nutrient digestibility are variable. Beede et al. (1986) reported increased DM digestibility in cattle fed diets containing low $\mathrm{CP}$ content when monensin

Table 4 - Nitrogen balance in wethers fed with diets containing high inclusion of flint corn with and without inclusion of monensin and narasin.

\begin{tabular}{|c|c|c|c|c|c|c|c|c|c|c|}
\hline \multirow{2}{*}{ Item } & \multicolumn{5}{|c|}{ Diets $^{1}$} & \multirow{2}{*}{$\mathrm{SEM}^{2}$} & \multicolumn{4}{|c|}{$p$-value ${ }^{3}$} \\
\hline & C & M & N5 & N10 & N15 & & $\mathrm{C} \times \mathrm{M}$ & $\mathrm{M} \times \mathrm{N}$ & L & Q \\
\hline $\mathrm{N}$ intake $\left(\mathrm{g} \mathrm{d}^{-1}\right)$ & 56.0 & 47.6 & 50.1 & 54.2 & 46.9 & 2.64 & 0.02 & 0.27 & 0.06 & 0.76 \\
\hline Fecal N $\left(\mathrm{g} \mathrm{d}^{-1}\right)$ & 9.55 & 6.80 & 8.98 & 8.29 & 6.67 & 0.65 & 0.01 & 0.13 & $<0.01$ & 0.43 \\
\hline $\mathrm{N}$ absorbed $\left(\mathrm{g} \mathrm{d}^{-1}\right)$ & 46.5 & 40.8 & 41.2 & 45.9 & 40.3 & 2.28 & 0.04 & 0.42 & 0.19 & 0.93 \\
\hline Urinary $\mathrm{N}\left(\mathrm{g} \mathrm{d}^{-1}\right)$ & 26.9 & 23.5 & 22.6 & 22.7 & 21.0 & 2.17 & 0.17 & 0.50 & 0.04 & 0.47 \\
\hline \multicolumn{11}{|l|}{$\mathrm{N}$ retention } \\
\hline $\mathrm{g} \mathrm{d}^{-1}$ & 19.6 & 17.3 & 18.6 & 23.2 & 19.3 & 2.54 & 0.52 & 0.31 & 0.63 & 0.58 \\
\hline $\mathrm{g} \mathrm{kg}^{-1}$ of $\mathrm{N}$ absorbed & 424 & 430 & 444 & 496 & 475 & 47.7 & 0.93 & 0.43 & 0.30 & 0.65 \\
\hline $\mathrm{g} \mathrm{kg}^{-1}$ of $\mathrm{N}$ intake & 351 & 369 & 364 & 421 & 407 & 40.4 & 0.75 & 0.54 & 0.19 & 0.74 \\
\hline
\end{tabular}

${ }^{1} \mathrm{C}=$ control diets, no additives; $\mathrm{M}=25 \mathrm{mg}$ of monensin $\mathrm{kg}^{-1}$ of DM; $\mathrm{N5}=5 \mathrm{mg}$ of narasin kg-1 of DM; $\mathrm{N10}=10 \mathrm{mg}$ of narasin kg ${ }^{-1}$ of DM; $\mathrm{N15}=15 \mathrm{mg}$ of narasin $\mathrm{kg}^{-1}$ of DM; ${ }^{2} \mathrm{SEM}=$ standard error of mean. ${ }^{3} \mathrm{C} \times \mathrm{M}=$ control diet vs. diet containing $25 \mathrm{mg}$ of monensin $\mathrm{kg}^{-1} \mathrm{DM} ; \mathrm{M} \times \mathrm{N}=\operatorname{diet}$ containing $25 \mathrm{mg}^{2}$ of monensin kg-1 vs. diets containing narasin; $L=$ linear effect of narasin (C, N5, N10 and N15); $Q=$ quadratic effect of narasin (C, N5, N10 and N15).

Table 5 - Body weight, average daily gain, dry matter intake, and feed efficiency of lambs fed with diets containing high inclusion of flint corn with and without inclusion of monensin and narasin.

\begin{tabular}{|c|c|c|c|c|c|c|c|c|c|c|c|c|}
\hline \multirow{2}{*}{ Item $^{4}$} & \multicolumn{5}{|c|}{ Diets $^{1}$} & \multirow{2}{*}{$\mathrm{SEM}^{2}$} & \multicolumn{6}{|c|}{$p$-value ${ }^{3}$} \\
\hline & C & $M$ & N5 & N10 & N15 & & $C \times M$ & $M \times N$ & $\mathrm{~L}$ & $Q$ & $P$ & $D \times P$ \\
\hline \multicolumn{13}{|l|}{ BW (kg) } \\
\hline Initial & 25.4 & 25.3 & 25.3 & 25.4 & 25.2 & 0.46 & - & - & - & - & - & - \\
\hline Day 14 & 28.7 & 28.3 & 28.8 & 29.3 & 29.2 & 0.41 & 0.51 & 0.09 & 0.21 & 0.80 & - & - \\
\hline Day 28 & 32.7 & 31.6 & 32.2 & 33.2 & 33.1 & 0.49 & 0.11 & 0.03 & 0.24 & 0.67 & - & - \\
\hline Day 42 & 36.8 & 36.1 & 36.1 & 38.0 & 37.8 & 0.55 & 0.38 & 0.07 & 0.04 & 0.70 & - & - \\
\hline Day 56 & 40.9 & 40.2 & 40.5 & 42.4 & 42.5 & 0.65 & 0.43 & 0.04 & 0.02 & 0.73 & - & - \\
\hline ADG (g) & 273 & 260 & 267 & 298 & 302 & 17.6 & 0.49 & 0.05 & 0.03 & 0.70 & $<0.01$ & 0.34 \\
\hline DMI $\left(\mathrm{g} \mathrm{d}^{-1}\right)$ & 1,093 & 1,044 & 1,063 & 1,134 & 1,129 & 55.8 & 0.35 & 0.14 & 0.23 & 0.72 & $<0.01$ & 0.33 \\
\hline $\mathrm{FE}$ & 0.252 & 0.252 & 0.253 & 0.260 & 0.273 & 0.012 & 0.94 & 0.27 & 0.04 & 0.43 & $<0.01$ & 0.64 \\
\hline
\end{tabular}

${ }^{1} \mathrm{C}=$ control diets, no additives; $\mathrm{M}=25 \mathrm{mg}$ of monensin $\mathrm{kg}^{-1}$ of DM; N5 = $5 \mathrm{mg}$ of narasin $\mathrm{kg}^{-1}$ of DM; $\mathrm{N} 10=10 \mathrm{mg}$ of narasin $\mathrm{kg}^{-1}$ of DM; N15 = $15 \mathrm{mg}$ of narasin $\mathrm{kg}^{-1}$ of DM; ${ }^{2} \mathrm{SEM}=$ standard error of mean. ${ }^{3} \mathrm{C} \times \mathrm{M}=$ control diet vs. diet containing $25 \mathrm{mg}$ of monensin $\mathrm{kg}^{-1} \mathrm{DM}$; M $\times \mathrm{N}^{-1}$ diet containing 25 mg of monensin $\mathrm{kg}^{-1}$ vs. diets containing narasin; $L=$ linear effect of narasin (C, N5, N10 and N15); Q = quadratic effect of narasin (C, N5, N10 and N15); P = effect of period or day of weighing; $\mathrm{D} \times \mathrm{P}=$ effect of the interaction between the experimental diets and period. ${ }^{4} \mathrm{BW}=$ body weight; $\mathrm{ADG}=$ average daily gain; $\mathrm{DMl}=\mathrm{dry}$ matter intake; $\mathrm{FE}=$ feed efficiency (feed gain-1). 
was used. In a literature review containing 20 studies evaluating the use of lasalocid and monensin, Spears (1990) reported an increase of approximately $2 \%$ in the digestible energy of the diets when these ionophores were used. Recent studies reported no differences in DM, OM, and NDF digestibility for beef steers fed with monensin (Bell et al., 2017) or narasin (Polizel et al., 2020).

Bacteria that reduce succinate to propionate are resistant to the effects of ionophores; therefore, when these additives are used, propionate production tends to increase during ruminal fermentation (McGuffey et al., 2001). The higher molar proportion of propionate and, consequently, lower Ac:pr ratio, increases the energy efficiency of the ruminal fermentation process, since a higher propionate production leads to an increase in hepatic gluconeogenesis flow (Baird et al., 1980), as propionate is the main glucose precursor for ruminant animals (Ellis et al., 2012). Moreover, propionate production reduces the amount of substrate for methanogenesis, decreasing the availability of hydrogen and formate (Ellis et al., 2008). Changes in the VFA formed during the ruminal fermentation process are essential for the mechanistic models to predict the enteric methane production and estimate energy losses (Bannink et al., 2011), because propionate is an important hydrogen sink in the rumen, while acetate and butyrate are the main hydrogen sources (Wolin, 1960). Thus, the lower Ac:pr ratio in the rumen environment is indicative of greater energy efficient of fermentation, as observed for wethers fed with $\mathrm{M}$ or $\mathrm{N}$.

Reduction in butyrate production when monensin is used for ruminants fed high concentrate diets is highly discussed in the literature. In a meta-analysis performed by Ellis et al. (2012), the authors verified that monensin doses used for cattle fed diets containing at least $80 \%$ of grains reduced the molar ratio of butyrate and increased propionate. The reduction in butyrate can be justified by the change in the population of microorganisms with the use of ionophore. Henderson et al. (1981) evaluated in vitro the effects of monensin on the bacterial population and reported differences in the amount and potential of inhibition of two different Butyrivibrio strains when using ionophore.

The feed additives investigated potentially affect $\mathrm{N}$ metabolism of ruminant animals (Bergen and Bates, 1984). In vitro studies have shown that monensin has the capacity to reduce protein degradation, ammonia accumulation, and microbial $\mathrm{N}$ (Whetstone et al., 1981). Chen and Russell (1991) reported that monensin had little effect on ruminal proteolysis; however, it caused a reduction in ammonia production. Additionally, the reduction in ammonia concentration may be associated with improved energy efficiency intrinsic to ruminal fermentation, as ammonia is more used by microorganisms, mainly in high-energy diets. The present study shows that monensin decreased ammonia concentration in rumen fluid, as described in the literature (Yang and Russell, 1993).
Few studies have evaluated the effect of narasin on N metabolism in ruminants. Polizel et al. (2020) reported lower ammonia concentration on rumen fluid and blood urea in steers fed high-forage diets with the inclusion of narasin; however, the authors did not evaluate $\mathrm{N}$ balance. In the present study, $\mathrm{N}$ had the capacity to decrease ammonia concentration; however, the decrease was lower than that promoted by $M$.

Experiment 2. Ionophores are molecules characterized by the transport of ions through cell membranes, possessing certain specificity for the molecules that are carried (Wong et al., 1977). The ruminal microorganism selection caused by ionophores has the objective to optimize the occurrence of desirable reactions, such as propionate production, and minimize inefficient or undesirable reactions, such as methane and lactate production. Changes in the ruminal fermentation process aim to improve energy efficiency of the animal, with positive responses on the weight gain and DMI (Duffield et al., 2012).

As expected, the inclusion of $\mathrm{N}$ increased ADG, final BW, and FE of lambs, which is an expected response of ionophores used in ruminant diets (Duffield et al., 2012). These effects could be explained by the changes caused by the ionophore in the ruminal fermentation process, by increasing molar proportion of propionate and reducing molar proportions of butyrate and acetate (Prange et al., 1978; Ellis et al., 2012).

The action of narasin in the ruminal environment is poorly understood. In an in vitro study, Nagaraja et al. (1987) reported an increase in the molar ratio of propionate using low doses of narasin. In addition, the authors observed a decrease in the production of lactic acid when compared to other additives. As previously described, Polizel et al. (2020) reported a reduction in the Ac:pr ratio and an increase in the total VFA concentration in cattle fed diets containing narasin, results that demonstrate an increase in the energy efficiency of the fermentation process. Therefore, further studies are needed to evaluate the effects of narasin on the ruminal environment, especially to identify the microorganisms affected by narasin inclusion.

An unexpected result in the present study was the lack of effect while using $M$, with results similar to C. In general, the use of $25 \mathrm{mg}$ of monensin $\mathrm{kg}^{-1}$ of DM results in an increase in $\mathrm{FE}$ in beef cattle and this effect is traditionally described by a reduction in DMI in the literature (Tedeschi et al., 2003). In a meta-analysis performed by Duffield et al. (2012), the authors noted that, in the last 40 years, the effect of monensin on FE decreased from 8 to $4 \%$ in feedlot cattle and this change might be explained partially by increases in dietary energy density and grain processing in feeding systems. These results led to questions regarding the monensin dose to be used for sheep. Studies conducted in the 1970s evaluated the inclusion of monensin doses on performance of lambs. Joyner et al. (1979) evaluated 
the inclusion of $0,5,10,20$, and $30 \mathrm{mg}$ of monensin $\mathrm{kg}^{-1}$ of the diet, and observed that $5 \mathrm{mg}$ of monensin was enough to increase FE of lambs. The same authors also evaluated indirect calorimetry using 12 lambs, which were fed with 0,10 , or $20 \mathrm{mg}$ of monensin. The authors reported a decrease in methane production and an increase in metabolizable energy for animals fed at 10 and $20 \mathrm{mg} \mathrm{kg}^{-1}$. That is, the lowest doses $(5$ or $10 \mathrm{mg} \mathrm{kg}^{-1}$ ) presented satisfactory results when added to sheep diets. Recently, Lodi et al. (2019) reported that the inclusion of $12.5 \mathrm{mg}$ of monensin $\mathrm{kg}^{-1}$ of DM increased ruminal $\mathrm{pH}$ without affecting DMI or feed behavior of lambs fed high-concentrate diets. In some cases, the use of $25 \mathrm{mg}$ of monensin aims to control coccidiosis (Polizel et al., 2017; Parente et al., 2018); however, few studies evaluate whether the inclusion of lower rates can control coccidiosis in small ruminants.

In conclusion, narasin inclusion in diets for feedlot lambs increased $\mathrm{ADG}$ and $\mathrm{FE}$, even when compared to monensin in diets containing high proportion of ground flint corn. This response could be promoted by greater total tract digestibility of $\mathrm{OM}, \mathrm{CP}$, and $\mathrm{NFC}$, lower Ac:pr ratio and rumen ammonia concentration. Better responses to narasin supplementation was observed at dosage of $15 \mathrm{mg} \mathrm{kg}^{-1}$ diet DM. In addition, the inclusion of $25 \mathrm{mg}$ monensin did not increase lamb performance despite the changes caused to the rumen fermentation process and nutrient digestibility.

\section{Acknowledgements}

The authors thank the Coordination for the Improvement of Higher Level Personnel (CAPES) for the first author scholarship.

\section{Authors' Contributions}

Conceptualization: Polizel, D.M.; Gouvea, V.N.; Ferreira, E.M.; Pires, A.V. Data acquisition: Polizel, D.M.; Marques, S.S.; Westphalen, M.F.; Gouvea, V.N.; Ferraz Jr., M.V.C. Data analysis: Polizel, D.M.; Miszura, A.A.; Barroso, J.P.R. Design of methodology: Polizel, D.M.; Ferraz Jr., M.V.C.; Ferreira, E.M.; Pires, A.V. Writing and editing: Polizel, D.M.; Miszura, A.A.; Ferreira, E.M.; Limede, A.C.; Pires, A.V.

\section{References}

Assis, R.G.; Biava, J.S.; Polizel, D.M.; Souza, T.T.; Sturion, T.U.; Pires, A.V.; Relling, A.E.; Ferreira, E.M. 2020. Use of narasin in diets for lactating ewes. Small Ruminant Research 187: 106108.

Association of Official Analytical Chemists [AOAC]. 1990. Official Methods of Analysis. AOAC, Arlington, VA, USA.

Baird, G.D.; Lomax, M.A.; Symonds, H.W.; Shaw, S.R. 1980. Net hepatic and splanchnic metabolism od lactate, pyruvate and propionate in dairy cows in vivo in relation to lactation and nutrient supply. Biochemical Journal 186: 47-57.
Bannink, A.; Van Schijndel, M.W.; Dijkstra, J. 2011. A model of enteric fermentation in dairy cows to estimate methane emission for the Dutch National Inventory Report using the IPCC tier 3 approach. Animal Feed Science and Technology 166-167: 603-618.

Beede, D.K.; Schelling, G.T.; Mitchell, G.E.; Tucker, R.E.; Gill, W.W.; Koenig, S.E.; Lindsey, T.O. 1986. Nitrogen utilization and digestibility by growing steers and goats of diets that contain monensin and low crude protein. Journal of Animal Science 62: 857-863.

Bell, N.L.; Anderson, R.C.; Callaway, T.R.; Franco, M.O.; Sawyer, J.E.; Wickersham, T.A. 2017. Effect of monensin inclusion on intake, digestion, and ruminal fermentation parameters by Bos taurus indicus and Bos taurus taurus steers consuming bermudagrass hay. Journal of Animal Science 95: 2736-2746.

Bergen, W.G.; Bates, D.B. 1984. Ionophores: their effect on production efficiency and mode of action. Journal of Animal Science 58: 1465-1483.

Chaney, A.L.; Marbach, E.P. 1962. Modified reagents for determination of urea and ammonia. Clinical Chemistry 8: 130-137.

Chen, G.C.; Russell, J.B. 1991. Effect of monensin and protonophore on protein degradation, peptide accumulation and deamination by mixed ruminal microorganisms in vitro. Journal of Animal Science 69: 2196-2203.

Duffield, T.F.; Merrill, J.K.; Bagg, R.N. 2012. Meta-analysis of the effects of monensin in beef cattle on feed efficiency, body weight gain and dry matter intake. Journal of Animal Science 90: 4583-4592.

Ellis, J.L.; Dijkstra, J.; Bannink, A.; Kebreab, E.; Hook, S.E.; Archibeque, S.; France, J. 2012. Quantifying the effect of monensin dose on the rumen volatile fatty acid profile in highgrain-fed beef cattle. Journal of Animal Science 90: 2717-2726.

Ellis, J.L.; Dijkstra, J.; Keabreab, E.; Bannink, A.; Odongo, N.E.; McBride, B.W.; France, J. 2008. Aspects of rumen microbiology central to mechanistic modeling of methane production in cattle. Journal of Agricultural Science 145: 409-417.

Goering, H.K.; Van Soest, P.J. 1970. Forage Fiber Analysis (Apparatus, Reagents, Procedures and Some Applications). ARS/-USDA, Washington, DC, USA. (Agriculture Handbook, 379).

Henderson, C.; Stewart, C.S.; Nekrep, F.V. 1981. The effect of monensin on pure and mixed culture of rumen bacteria. Journal of Applied Bacteriology 51: 159-169.

Joyner, A.E.; Brown, L.J.; Fogg, T.J.; Rossi, R.T. 1979. Effect of monensin on growth, feed efficiency and energy metabolism of lambs. Journal of Animal Science 48: 1065-1069.

Lodi, F.; Ferreira, E.M.; Biava, J.S.; Martins, M.C.; Assis, R.G.; Moletta, J.L.; Araújo, L.C.; Pedrosa, V.B.; Polizel, D.M.; Pires, A.V. 2019. Lemon grass essential oil (Cymbopogum flexuosus) in high-concentrate diets for lambs. Archives of Veterinary Science 24: 33-37.

McGuffey, R.K.; Richardson, L.F.; Wilkinson, J.I. 2001. Ionophores for dairy cattle: current status and future outlook. Journal of Dairy Science 84: 194-203.

Mertens, D.R. 1997. Creating a system for meeting the fiber requirements of dairy cows. Journal of Dairy Science 80: 14631481. 
Meyer, N.F.; Erickson, G.E.; Klopfenstein, T.J.; Benton, J.R.; Luebbe, M.K.; Laudert, S.B. 2013. Effects of monensin and tylosin in finishing diets containing corn wet destillers grains with solubles with differing corn processing methods. Journal of Animal Science 91: 2219-2228.

Nagaraja, T.G.; Taylor, M.B.; Harmon, D.L.; Boyer, J.E. 1987. In vitro lactic acid inhibition and alterations in volatile fatty acid production by antimicrobial feed additives. Journal of Animal Science 65: 1064-1076.

National Research Council [NRC]. 2007. Nutrient Requirements of Small Ruminants: Sheep, Goats, Cervids, and New World Camelids. NRC, Washington, DC, USA.

Oliveira, C.A.; Millen, D.D. 2014. Survey of the nutritional recommendations and management practices adopted by feedlot cattle nutritionists in Brazil. Animal Feed Science and Technology 197: 64-75.

Parente, M.O.M.; Susin, I.; Nolli, C.P.; Ferreira, E.M.; Gentil, R.S.; Polizel, D.M.; Pires, A.V.; Alves, S.P.; Bessa, R.J.B. 2018. Effects of supplementation with vegetable oils, including castor oil, on milk production of ewes and on growth of their lambs. Journal of Animal Science 96: 354-363.

Pasqualino, L.F.; Oliveira, G.B.; Miszura, A.A.; Barroso, J.P.R.; Limede, A.C.; Sardinha, L.A.; Biava, J.S.; Ferreira, E.M.; Pires, A.V.; Polizel, D.M. 2020. Residual effect of narasin on ruminal fermentation characteristics in lambs. Livestock Science 204: 104141.

Philippeau, C.; Monredon, L.D.; Michalet-Doreau, B. 1999. Relationship between ruminal starch degradation and the physical characteristics of corn grain. Journal of Animal Science 77: 238-243.

Polizel, D.M.; Cappellozza, B.I.; Hoe, F.; Lopes, C.N.; Barroso, J.P.; Miszura, A.; Oliveira, G.B.; Gobato, L.; Pires, A.V. 2020. Effects of narasin supplementation on dry matter intake and rumen fermentation characteristics of Bos indicus steers fed a high-forage diets. Translational Animal Science 4: 1-11.

Polizel, D.M.; Susin, I.; Gentil, R.S.; Ferreira, E.M.; Souza, R.A.; Freire, A.P.A.; Pires, A.V.; Ferraz Jr., M.V.C.; Rodrigues, P.H.M.; Eastridge, M.L. 2017. Crude glycerin decreases nonesterified fatty acid concentration in ewes during late gestation and early lactation. Journal of Animal Science 95: 875-883.
Prange, R.W.; Davis, C.L.; Clark, J.H. 1978. Propionate production in the rumen of Holstein steers fed either a control or monensin supplemented diet. Journal of Animal Science 46: 1120-1124.

Pressman, B.V. 1976. Biological applications of ionophores. Annual Review of Biochemistry 45: 501-530.

Sardinha, L.A.; Marques, R.S.; Miszura, A.A.; Barroso, J.P.R.; Oliveira, G.B.; Martins, A.S.; Limede, A.C.; Ferraz Jr., M.V.C.; Ferreira, E.M.; Pires, A.V.; Eastridge, M.L.; Polizel, D.M. 2020. Milk yield and composition from ewes fed diets containing narasin and their lambs' performance. Translational Animal Science 4: 1-9.

Spears, J.W. 1990. Ionophore and nutrient digestion and absorption in ruminants. Journal Nutrition 120: 632-638.

Tedeschi, L.O.; Fox, D.G.; Tylutki, T.P. 2003. Potential environmental benefits of ionophore in ruminant diets. Journal of Environmental Quality 32: 1591-1602.

Van Soest, P.J.; Robertson, J.B.; Lewis, B.A. 1991. Methods for dietary fiber, neutral detergent fiber, and nonstarch polysaccharides in relation to animal nutrition. Journal of Dairy Science 74: 3583-3597.

Whetstone, H.D.; Davis, C.L.; Bryant, M.P. 1981. Effect of monensin on breakdown of protein by ruminal microorganisms in vitro. Journal of Animal Science 53: 803-809.

Wolin, M.J. 1960. A theoretical rumen fermentation balance. Journal of Dairy Science 43: 1452-1459.

Wong, D.T.; Berg, D.H.; Hamill, R.H.; Wilkinson, J.R. 1977. Ionophores properties of narasin, a new polyether monocarboxylic acid antibiotic, in rat liver mitochondria. Biochemical Pharmacology 26: 1373-1376.

Yang, C.M.J.; Russell, J.B. 1993. Effect of monensin on the specific activity of ammonia production by ruminal bacteria and disappearance of amino nitrogen from the rumen. Applied and Environmental Microbiology 59: 3250-3254. 